\title{
Morphological diversity in sorghum germplasm from India
}

\author{
S. Appa Rao ${ }^{1}$, K.E. Prasada Rao, M.H. Mengesha \& V. Gopal Reddy \\ Genetic Resources Division, International Crops Research Institute for the Semi-Arid Tropics, Patancheru, \\ Andhra Pradesh 502 324, India; ' present address: Lao-IRRI Project, P.O. Box 4195, Vientiane, Lao PDR.
}

Received 2 March 1995; accepted in revised form 12 March 1996

Key words: evaluation, sorghum, diversity, races, germplasm utilization, genetic stocks, agronomic traits

\section{Summary}

Of the 5000 sorghum (Sorghum bicolor L. Monench) germplasm accessions assembled at ICRISAT Asia Center (IAC), over 4000 accessions from 11 major sorghum growing states in India were evaluated for morphological and agronomical characters at IAC during rainy and postrainy seasons.

Considerable diversity was observed for all the characters studied. Diversity was more among states than within states. Variation among the seasons was also considerable. Days to flowering ranged from 42 to 129 days during postrainy and 33 to 180 days during the rainy season indicating their day length sensitivity. Plant height ranged from 65 to $330 \mathrm{~cm}$ during postrainy and 75 to $655 \mathrm{~cm}$ during rainy season. Panicle length ranged from $5 \mathrm{~cm}$ to $52 \mathrm{~cm}$ and panicle width from 1 to $51 \mathrm{~cm}$. Erect and compact panicles are more frequent although all possible panicle shapes and compactness were found. In general, sorghums from India produce medium to large, lustrous grains in which the subcoat (testa) is absent. All the 5 basic and 10 intermediate sorghum races were found in India though durra or half-durra predominate. Racial diversity is maximal in the state of Andhra Pradesh followed by Maharashatra state. In the world collection a majority of the sources of resistance to shoot fly, stem borer, and striga are from India. Based on diversity for morphological and agronomical characters, India could be considered as the secondary center of diversity. Sorghum germplasm from India is useful for good quality large grain.

\section{Introduction}

In India, sorghum (Sorghum bicolor L. Moench) is the third most important food crop which is grown on an estimated 13.3 million ha producing 12.5 million tons annually (FAO, 1993). The area and production of sorghum have been fluctuating considerably from 11.34 to 8.8 million hectares producing 5.347 million tons to 8.770 million tons during the rainy (kharif), and 5.31 million ha to 7.354 million tons during winter (rabi) season producing 1.621 million tons to 3.651 million tons from 1962 to 1991 (Murty, 1992). In general, about $60 \%$ of sorghum is grown during rainy and $40 \%$ being grown during the postrainy or winter season. In general, about $60 \%$ of the total area and $66 \%$ of the annual production comes from the rainy season crop, $40 \%$ being grown during the postrainy accounting for $34 \%$ of the annual production. In general, grain produced during the rainy season is relatively inferior because of grain deterioration compared to that produced during the postrainy season due to the absence of rain at grain filling and maturity. Hence, most of the grain produced from the rainy season is used as poultry and animal feed, while the grain produced during the postrainy season is used for human consumption. Although there has been a continuous decrease in areas since 1961 to 1993 , the total production in the country is now on the increase which is mainly due to increased production in the rainy season with a marginal increase in the postrainy season. In spite of the availability of several improved cultivars including hybrids, there has been only a marginal increase in grain yield. To achieve a noticeable increase in grain yield and for stability and global food security, there is need to broaden the genetic base of the sorghum cultivars (Swaminathan \& Jana, 1992; Paroda \& Arora, 1992; Duncan et al., 1991; Eberhart, 1993). 
The largest world collection of sorghum have been conserved at IAC, at Fort Collins in USA, and in Puerto Rico (Duncan et al., 1993; Eberhart, 1993; Dahlberg, 1993). The fast vanishing sorghum germplasm from India have been assembled as early as 1963 by the Rockefeller Foundation in India (Murty et al., 1967) and subsequently by ICRISAT since 1972 (Prasada Rao et al., 1989). So far, 5116 sorghum germplasm accessions from India have been assembled and conserved at the genetic resources division (GRD) at ICRISAT Asia Center (IAC), Patancheru. This is the largest collection of Indian sorghum maintained anywhere in the world. Of these, 4,289 accessions orginate predominantly from Deccan plateau that include the states of Andhra Pradesh, Madhya Pradesh, Maharashtra, and Karnataka which are also the most important states interms of sorghum cultivation. All these accessions were evaluated at IAC during the rainy and postrainy seasons for morphologic and agronomical characters. This paper describes the diversity observed in Indian sorghums from 11 states for morphological and agronomic characters, their classification and their possible use in sorghum improvement programs.

\section{Materials and methods}

For characterization and evaluation, sorghum germplasm accessions were sown at IAC Patancheru $\left(17^{\circ} 25^{\prime}\right.$ latitude and $78^{\circ}$ longitude) on vertisols during the rainy season in the second fortnight of June and harvested in November-December. Observations on days-to-flower, plant height, were recorded only in the rainy season. The same accessions were sown again in the postrainy season during the second fortnight of September and harvested in March-April. Only supplementary irrigation was carried out during the rainy season, while regular irrigation was provided during the postrainy season. During this season, plant, panicle and grain characters were recorded. Observations on midrib color were recorded at flag leaf stage, and other characters between flowering and maturity. Grain characters were recorded after harvest in the laboratory. Days to flower is the number of days from the mean emergence date to the date when $50 \%$ plants have started flowering. Plant height is the length of the main stalk (in cm) at maturity. Ten selected plants of each accession were measured and the mean computed. Inflorescence exsertion is measured as the amount of exposed peduncle from the flag leaf to the base of panicle. Inflorescence length and width were also mea- sured at maturity as the maximum length from base of panicle to the tip of panicle, and maximum width in the natural position. Grain covering indicates the amount of grain covered by glumes at maturity. This is one of the distinguishing characters used in the racial classification of cultivated sorghum. Grain mass is the weight in grams of 100 grains at a moisture content of about $12 \%$. The method and stage of recording different characters were described in more detail by Prasada Rao \& Ramanatha Rao (1995). Accessions in which the data was incomplete for some traits or which could not be recorded were excluded from statistical analysis. The data was analyzed using SAS users guide (SAS Institute, 1982).

\section{Results and discussion}

Considerable diversity was observed for all the characters studied and is substantially higher among different states than within a state. However, variation was enormous between the two seasons particularly for flowering and plant height. Variation in some landraces was enormous during different seasons showing a differential response of landraces adapted to various seasons. The rainy season at IAC and sorghum growing areas in India was characterized by long days, relatively higher temperatures, humid and cloudy weather conditions. The postrainy season is characterized by shorter day-length, lower temperature and dry weather conditions. Changes in temperature and day length might be responsible for differential response in the two contrasting seasons.

\section{Vegetative characters}

Plant pigmentation is a juvenile characteristic useful in identifying landraces. Tan plants are preferred in sorghum improvement as this character does not impart color to the developing grain when it rains. There are very few (172) accessions with this character in the collection and these are mainly from Ethiopia (Prasada Rao et al., 1989). Tan plants are completely absent from Gujarat, Punjab, and Rajasthan (Table 1). The pigmented plants are in a majority and number 3976 in the collection. Midrib color is also a juvenile character and is associated with stalk juiciness where juicy sweet stalks are chewed like sugarcane particularly in southern Africa (Appa Rao et al., 1989; Appa Rao et al., 1992). In India, the white midrib character predomi- 
Table 1. Geographic diversity for plant pigmentation, midrib color and threshability of sorghum germplasm from different states in India

\begin{tabular}{|c|c|c|c|c|c|c|c|c|}
\hline \multirow[t]{2}{*}{ State } & \multirow[t]{2}{*}{ No. Acc. } & \multicolumn{2}{|l|}{ Pig } & \multicolumn{2}{|l|}{$\mathrm{MRC}$} & \multicolumn{3}{|l|}{ Thr. } \\
\hline & & $\mathrm{P}$ & $\mathrm{T}$ & $\bar{D}$ & W & DT & FT & PT \\
\hline Andhra Pradesh & 814 & 687 & 122 & 283 & 526 & 20 & 541 & 208 \\
\hline Bihar & 187 & 182 & 5 & 5 & 183 & 10 & 75 & 39 \\
\hline Gujarat & 200 & 200 & 0 & 108 & 92 & 2 & 34 & 164 \\
\hline Kamataka & 416 & 412 & 3 & 162 & 253 & 5 & 200 & 206 \\
\hline Madhya Pradesh & 789 & 777 & 5 & 69 & 713 & 12 & 465 & 257 \\
\hline Maharashtra & 731 & 715 & 13 & 439 & 289 & 25 & 325 & 373 \\
\hline Orissa & 149 & 136 & 13 & 24 & 125 & 3 & 65 & 13 \\
\hline Punjab & 144 & 144 & 0 & 28 & 116 & 30 & 25 & 89 \\
\hline Rajasthan & 237 & 236 & 0 & 13 & 223 & 9 & 74 & 154 \\
\hline Tamil Nadu & 254 & 244 & 10 & 38 & 216 & 46 & 79 & 123 \\
\hline Uttar Pradesh & 245 & 243 & 1 & 7 & 237 & 17 & 114 & 114 \\
\hline Total & 4166 & 3976 & 172 & 1176 & 2973 & 179 & 1997 & 1740 \\
\hline
\end{tabular}

Pig = Plant pigmentation $(P=$ pigmented, $T=\tan ) ; M R C=$ Midrib color $(\mathrm{D}=$ dull, $\mathrm{W}=$ white)

Thr $=$ Thresability $(\mathrm{DT}=$ difficult, $\mathrm{FT}=$ Freely, $\mathrm{PT}=$ Party difficult $)$

Table 2. Geographic Diversity for days to flower and plant height in sorghum germplasm from different states in India during the rainy and postrainy seasons

\begin{tabular}{lcllllllll}
\hline State & No. & $\begin{array}{l}\text { DFLR } \\
\text { Range }\end{array}$ & $\begin{array}{l}\text { DFLR } \\
\text { Mean } \pm \text { SE }\end{array}$ & $\begin{array}{l}\text { DFLK } \\
\text { Range }\end{array}$ & $\begin{array}{l}\text { DFLK } \\
\text { Mean } \pm \text { SE }\end{array}$ & $\begin{array}{l}\text { PHTR } \\
\text { Range }\end{array}$ & $\begin{array}{l}\text { PHTR } \\
\text { Mean } \pm \text { SE }\end{array}$ & $\begin{array}{l}\text { PHTK } \\
\text { Range }\end{array}$ & $\begin{array}{l}\text { PHTK } \\
\text { Mean } \pm \text { SE }\end{array}$ \\
\hline Andhra & 810 & $48-114$ & $73 \pm 0.3$ & $42-180$ & $95 \pm 1$ & $65-295$ & $183 \pm 1.6$ & $75-560$ & $331 \pm 3.8$ \\
Pradesh & & & & & & & & & \\
Bihar & 187 & $54-95$ & $65 \pm 0.5$ & $50-15-$ & $102 \pm 1.7$ & $110-285$ & $193 \pm 1.9$ & $160-590$ & $374 \pm 6.4$ \\
Gujarat & 200 & $44-96$ & $63 \pm 0.5$ & $50-144$ & $83 \pm 1.3$ & $100-280$ & $202 \pm 1.9$ & $160-520$ & $321 \pm 4.5$ \\
Karnataka & 415 & $47-110$ & $75 \pm 0.5$ & $56-156$ & $93 \pm 1$ & $80-310$ & $222 \pm 1.5$ & $80-555$ & $379 \pm 3.1$ \\
Madhya & 782 & $50-92$ & $64 \pm 0.2$ & $50-150$ & $97 \pm 0.6$ & $100-330$ & $206 \pm 1.1$ & $100-555$ & $376 \pm 2.4$ \\
Pradesh & & & & & & & & & \\
Maharashtra & 728 & $45-129$ & $71 \pm 0.6$ & $48-154$ & $91 \pm 0.8$ & $68-320$ & $207 \pm 1.4$ & $95-540$ & $331 \pm 2.6$ \\
Orissa & 149 & $53-96$ & $70 \pm 0.4$ & $53-157$ & $119 \pm 1.4$ & $110-275$ & $205 \pm 2.1$ & $135-560$ & $407 \pm 5.9$ \\
Punjab & 144 & $45-100$ & $57 \pm 0.7$ & $33-144$ & $63 \pm 1.3$ & $145-260$ & $194 \pm 1.9$ & $155-495$ & $254 \pm 6.4$ \\
Rajasthan & 236 & $45-92$ & $59 \pm 0.5$ & $55-135$ & $77 \pm 0.8$ & $100-280$ & $190 \pm 2.0$ & $155-430$ & $314 \pm 4.5$ \\
Tamil Nadu & 239 & $46-106$ & $69 \pm 0.5$ & $48-153$ & $89 \pm 1.9$ & $110-300$ & $208 \pm 2.4$ & $110-655$ & $354 \pm 6.7$ \\
Uttar Pradesh & 243 & $42-86$ & $59 \pm 0.4$ & $47-140$ & $80 \pm 1.0$ & $115-320$ & $206 \pm 1.7$ & $80-500$ & $343 \pm 4.9$ \\
\hline
\end{tabular}

DFLR $=$ Days to $50 \%$ flowering in the postrainy season; DFLK $=$ Days to $50 \%$ flowering in the rainy season.

PHTR = Plant height $(\mathrm{cm})$ in the postrainy season; PHTK = Plant height $(\mathrm{cm})$ in the rainy season

nates (2973), followed by dull midrib (1176), while a brown midrib is completely absent.

\section{Days to flower}

In the rainy season some accessions do not flower as most of the tropical germplasm is photoperiod sensitive during this season because of the longer daylength. With a shorter daylength in the postrainy season, all the accessions, including those from tropical African countries, flowered in a relatively shorter time. Time to flowering varied considerably both within a state, among different states and between the two seasons. For example diversity for days to flowering is enormous in Maharashtra which ranged from 45 to 120 days with a mean of 71 days in postrainy and 48 to 154 days with a mean of 90 days during rainy season (Table 2), while it is less in Uttar Pradesh where 
Table 3. Geographic diversity for head length, head width, head exsertion and grain weight in sorghum germplasm from different states in India

\begin{tabular}{lcclllllll}
\hline State & No. & $\begin{array}{l}\text { Head } \\
\text { length } \\
\text { Range }\end{array}$ & $\begin{array}{l}\text { Head } \\
\text { length } \\
\text { Mean } \pm \text { SE }\end{array}$ & $\begin{array}{l}\text { Head } \\
\text { width } \\
\text { Range }\end{array}$ & $\begin{array}{l}\text { Head } \\
\text { width } \\
\text { Mean } \pm \text { SE }\end{array}$ & $\begin{array}{l}\text { Exser } \\
\text { tion } \\
\text { Range }\end{array}$ & $\begin{array}{l}\text { Exser } \\
\text {-tion } \\
\text { Mean } \pm \text { SE }\end{array}$ & $\begin{array}{l}\text { Grain } \\
\text { weight } \\
\text { Range }\end{array}$ & $\begin{array}{l}\text { Grain } \\
\text { weight } \\
\text { Mean } \pm \text { SE }\end{array}$ \\
\hline Andhra Prad & 810 & $7-41$ & $17.5 \pm 0.23$ & $3-33$ & $8.1 \pm 0.3$ & $0-39$ & $10.9 \pm 0.29$ & $0.6-5.0$ & $3.0 \pm 0.03$ \\
Bihar & 187 & $10-40$ & $24.6 \pm 0.51$ & $4-27$ & $14.2 \pm 40$ & $0-39$ & $17.7 \pm 0.57$ & $1.1-4.9$ & $2.2 \pm 0.40$ \\
Gujarat & 200 & $6-36$ & $1.3 .2 \pm 0.33$ & $3-21$ & $6.4 \pm 0.13$ & $0-35$ & $10.1 \pm 0.48$ & $0.9-5.1$ & $2.7 \pm 0.05$ \\
Karnataka & 415 & $7-52$ & $16.10 \pm .28$ & $1-51$ & $7.8 \pm 0.18$ & $0-37$ & $9.8 \pm 0.39$ & $1.4-5.2$ & $3.0 \pm 0.03$ \\
Madhya Prad & 782 & $8-52$ & $19.1 \pm 0.24$ & $1-34$ & $9.7 \pm 0.17$ & $0-37$ & $14.5 \pm 0.29$ & $1.2-7.3$ & $3.3 \pm 0.03$ \\
Maharashtra & 728 & $5-41$ & $15.7 \pm 0.19$ & $1-21$ & $7.1 \pm 0.07$ & $0-34$ & $10.0 \pm 0.27$ & $0.6-5.8$ & $3.2 \pm 0.02$ \\
Orissa & 149 & $8-47$ & $28.8 \pm 0.56$ & $5-33$ & $16.6 \pm 0.41$ & $0-36$ & $19.0 \pm 0.62$ & $1.3-3.1$ & $2.1 \pm 0.02$ \\
Punjab & 144 & $7-36$ & $17.8 \pm 0.52$ & $3-25$ & $8.4 \pm 0.27$ & $0-40$ & $17.8 \pm 0.77$ & $0.5-5.2$ & $2.1 \pm 0.05$ \\
Rajasthan & 236 & $6-35$ & $13.5 \pm 0.32$ & $2-20$ & $7.0 \pm 0.14$ & $0-55$ & $13.0 \pm 0.64$ & $1.0-4.7$ & $2.9 \pm 0.05$ \\
Tamil Nadu & 239 & $5-35$ & $16.1 \pm 0.48$ & $3-22$ & $7.3 \pm 0.25$ & $0-47$ & $15.2 \pm 0.69$ & $1.0-5.1$ & $2.4 \pm 0.04$ \\
Uttar Pradesh & 243 & $7-49$ & $18.9 \pm 0.39$ & $4-29$ & $9.0 \pm 0.22$ & $0-45$ & $17.8 \pm 0.56$ & $0.6-6.2$ & $2.7 \pm 0.06$ \\
\hline
\end{tabular}

it ranged from 42 to 59 days during postrainy season and 47 to 140 days with a mean of 80 days during rainy season (Table 2 ). Strongly photoperiod sensitive forms were found in the tribal-inhabited areas of Andhra Pradesh, Orissa, Bihar, and Madhya Pradesh which flowered in 180 days during the rainy season while they flowered in 114 days during the postrainy season. In areas where photoperiod sensitive sorghum is grown during the postrainy season, diversity for days to flowering is enormous. Photoperiod sensitive forms mature after the cessation of rains and enable them to escape grain mold which is likely to happen. In these high rainfall areas if sorghums mature after the cessation of rains they produce mold free grain (Rao, 1982). Early maturing forms were found in germplasm from Punjab, Rajasthan, and Andhra Pradesh where they are grown in lower rainfall areas, or where the selection has been for early maturity to meet food requirements before the paddy crop would be ready for harvesting by the subsistence farmers in these areas. The delay in flowering during rainy season compared to postrainy season is mainly because of strong photoperiod sensitivity and that there is considerable variation in daylength during the rainy and postrainy seasons at IAC. As sorghum has been postulated to have originated in the north east quadrant of Africa (Mann et al., 1983 Doggett, 1988) and was transported to India only about 3000 years ago, it is a short day plant though some day neutral landraces are available.

\section{Plant height}

Diversity for plant height was great as it ranged from $65 \mathrm{~cm}$ to $330 \mathrm{~cm}$ during the rainy and $75 \mathrm{~cm}$ to $655 \mathrm{~cm}$ during the postrainy season. Mean plant height ranged from 183 to $221 \mathrm{~cm}$ during the postrainy and 254 to $406 \mathrm{~cm}$ during the rainy season (Table 3 ). The reduced plant height during postrainy season is due to the lower temperature and shorter photoperiod which retards growth resulting in reduced plant height. The considerable increase in plant height during the rainy season is due to the higher temperature, longer day-length and longer growing season which encourage growth. Accessions from Orissa which grow about $275 \mathrm{~cm}$ tall in the postrainy season grow over $406 \mathrm{~cm}$ tall in the rainy season. In general, those accessions which take more time to flower grow taller in the rainy season and produce a higher biomass making them suitable for dual purpose (grain and forage) types. Some of these accessions from Tamil Nadu produced the tallest plants followed by Bihar, Andhra Pradesh and Orissa which are valuable for their high biomass production.

\section{Inflorescence characters}

Panicle exsertion. Panicles held within the boot harbor insects and encourage diseases as the wet conditions within the boot are congenial for their development. Landraces in general, have poor exsertion, compared to the improved cultivars which produce longer penduncles. Sorghum plants of the subrace rox- 
Table 4. Geographic diversity for head compactness and shape of sorghum germplasm from different states in India

\begin{tabular}{|c|c|c|c|c|c|c|c|c|c|c|c|}
\hline \multirow[t]{2}{*}{ State } & \multirow[t]{2}{*}{ No. Acc } & \multicolumn{10}{|c|}{ Head compactness $\&$ shape } \\
\hline & & $\mathrm{CE}$ & $\mathrm{CO}$ & LDB & LSB & SCE & SCO & SDB & SSB & VLD & LSB \\
\hline Andhra Pradesh & 814 & 163 & 68 & 24 & 26 & 317 & 31 & 6 & I64 & 8 & 0 \\
\hline Bihar & 187 & 11 & 0 & 25 & 82 & 18 & 1 & 3 & 26 & 12 & 9 \\
\hline Gujarat & 200 & 109 & 25 & 2 & 0 & 41 & 14 & 0 & 9 & 0 & 0 \\
\hline Kamataka & 416 & 186 & 19 & 4 & 14 & 146 & 11 & 1 & 32 & 2 & 0 \\
\hline Madhya Pradesh & 789 & 240 & 48 & 50 & 81 & 196 & 24 & 9 & 126 & 5 & 5 \\
\hline Maharashtra & $73 I$ & 327 & 61 & 13 & 9 & 217 & 50 & 1 & 50 & 0 & 0 \\
\hline Orissa & 149 & 3 & 0 & 36 & 68 & 1 & 0 & 1 & 16 & 18 & 6 \\
\hline Punjab & 144 & 27 & 4 & 8 & 20 & 30 & 6 & 6 & 43 & 0 & 0 \\
\hline Rajasthan & 237 & 140 & 9 & 3 & 4 & 47 & 8 & 3 & 22 & 0 & 0 \\
\hline Tamil Nadu & 254 & 72 & 34 & 17 & 45 & 37 & 5 & 2 & 42 & 0 & 0 \\
\hline Uttar Pradesh & 245 & 47 & 2 & 5 & 14 & 97 & 13 & 6 & 58 & 0 & 0 \\
\hline Total & 4166 & 1325 & 270 & 187 & 363 & 1147 & 163 & 38 & 588 & 45 & 20 \\
\hline
\end{tabular}

$\mathrm{CE}=$ compact elliptic, $\mathrm{CO}=$ compact oval, $\mathrm{LDB}=$ loose drooping branches; $\mathrm{LSB}=$ Loose stiff branches, SCE = Semi-compact elliptic, SCO = Semi-compact oval, SDB = Semi-loose drooping branches, SSB = Semi-loose stiff branches, VLD $=$ Very loose drooping branches, and VLB $=$ Very loose stiff branches

Table 5. Geographic diversity for grain color of sorghum germplasm from different states in India

\begin{tabular}{llrrrrrrrrrrr}
\hline State & No. Acc. & B & CW & G & LB & LR & P & R & RB & S & W & Y \\
\hline Andhra Pradesh & 814 & 7 & 3 & 3 & 4 & 38 & 1 & 10 & 10 & 328 & 163 & 243 \\
Bihar & 187 & 8 & 3 & 2 & 6 & 2 & 0 & 0 & 24 & 17 & 122 & 3 \\
Gujarat & 200 & 1 & 4 & 1 & 3 & 11 & 1 & 0 & 3 & 83 & 90 & 3 \\
Karnataka & 416 & 10 & 3 & 0 & 0 & 31 & 0 & 16 & 2 & 299 & 33 & 21 \\
Madhya Pradesh & 789 & 10 & 5 & 3 & 14 & 15 & 1 & 7 & 6 & 323 & 395 & 4 \\
Maharashtra & 731 & 10 & 9 & 15 & 5 & 24 & 2 & 15 & 8 & 410 & 174 & 57 \\
Orissa & 149 & 8 & 0 & 0 & 11 & 0 & 0 & 0 & 3 & 21 & 105 & 1 \\
Punjab & 144 & 42 & 0 & 0 & 17 & 4 & 0 & 0 & 11 & 36 & 33 & 1 \\
Rajasthan & 237 & 5 & 4 & 0 & 6 & 13 & 1 & 3 & 5 & 112 & 84 & 4 \\
Tamil Nadu & 254 & 8 & 3 & 0 & 7 & 44 & 0 & 1 & 5 & 59 & 89 & 28 \\
Uttar Pradesh & 245 & 20 & 4 & 0 & 3 & 13 & 0 & 3 & 15 & 98 & 87 & 1 \\
Total & 4166 & 129 & 38 & 24 & 76 & 195 & 6 & 55 & 92 & 1786 & 1375 & 366 \\
\hline
\end{tabular}

$\mathrm{B}=$ brown, $\mathrm{CW}=$ chalky white, $\mathrm{G}=$ grey, $\mathrm{LB}=$ light brown, $\mathrm{LR}=$ light red, $\mathrm{P}=$ purple, $\mathrm{R}=$ red, $\mathrm{RB}=$ reddish brown, $S=$ straw, $W=$ white, $Y=$ yellow.

burghii, race guinea produce long peduncles, while some durra sorghumas produce panicles with poor exsertion. The range in variation for exsertion was greater in Rajasthan, followed by Tamil Nadu and Uttar Pradesh, while the mean exsertion was greater in Orissa as plants of the subrace roxburghii produce long peduncles (Table 4). Exsertion is poor in Karnataka, Andhra Pradesh, and Maharashtra where the postrainy sorghum is extensively grown.

Head length and width. There is enormous diversity for head length and width. These are important com- ponents which contribute to yield. Panicle length is a stable character which is a characteristic feature of a particular race (Mann et al., 1983; Doggett, 1988; Harlan, 1992). Panicle length ranged from 5 to $52 \mathrm{~cm}$ while the mean ranged from 13 to $28 \mathrm{~cm}$ (Table 5). The long panicle found in Madhya Pradesh and Karnataka belong to the subrace roxburghii (race guinea). Mean panicle length $(29 \mathrm{~cm})$ is greatest in Orissa, with most of the plants belonging to the subrace roxburghii. The accessions with short, compact, and oval panicles, majority of which belong to race durra, are from Tamil Nadu, Gujarat, Maharashtra and Rajasthan. 
Table 6. Geographic diversity for subcoat, lustre and endosperm texture of sorghum germplasm from different states in India

\begin{tabular}{|c|c|c|c|c|c|c|c|c|c|c|}
\hline \multirow[t]{2}{*}{ State } & \multirow[t]{2}{*}{ No. Acc. } & \multicolumn{2}{|c|}{ Subcoat } & \multicolumn{2}{|c|}{ Lustre } & \multicolumn{5}{|c|}{ Endosperm texture } \\
\hline & & $\bar{P}$ & $\bar{A}$ & $\mathrm{~L}$ & $\mathrm{NL}$ & 1 & 2 & 3 & 4 & 5 \\
\hline Andhra Pradesh & 814 & 22 & 784 & 782 & 24 & 29 & 112 & 428 & 226 & 11 \\
\hline Bihar & 187 & 37 & 150 & 147 & 40 & 12 & 74 & 66 & 32 & 2 \\
\hline Gujarat & 200 & 9 & 191 & 190 & 10 & 4 & 25 & 127 & 39 & 5 \\
\hline Kamataka & 416 & 9 & 406 & 406 & 9 & 6 & 22 & 251 & 126 & 9 \\
\hline Madhya Pradesh & 789 & 38 & 743 & 743 & 38 & 25 & 138 & 399 & 201 & 15 \\
\hline Maharashtra & 731 & 45 & 684 & 679 & 50 & 8 & 34 & 355 & 270 & 62 \\
\hline Orissa & 149 & 22 & 126 & 128 & 20 & 35 & 86 & 14 & 13 & 0 \\
\hline Punjab & 144 & 67 & 77 & 75 & 69 & 1 & 22 & 61 & 60 & 0 \\
\hline Rajasthan & 237 & 20 & 217 & 215 & 22 & 1 & 33 & 150 & 49 & 3 \\
\hline Tamil Nadu & 254 & 24 & 230 & 228 & 26 & 19 & 47 & 93 & 90 & 5 \\
\hline Uttar Pradesh & 245 & 30 & 213 & 206 & 37 & 4 & 28 & 118 & 90 & 3 \\
\hline Total & 4166 & 323 & 3821 & 3799 & 345 & 144 & 621 & 2062 & 1196 & 115 \\
\hline
\end{tabular}

Subcoat: $\mathrm{P}=$ present, $\mathrm{A}=$ absent; Grain lustre: $\mathrm{L}=$ lustrous, $\mathrm{NL}=$ non-lustrous

Endosperm texture (visually scored): $1=$ corneous, 3 = intermediate, $5=$ starchy

Head width ranged from 1 to $34 \mathrm{~cm}$ while the mean ranged from 6 to $16 \mathrm{~cm}$ (Table 5). The loose drooping panicles of subrace roxburghii commonly found in tribal inhabited hilly areas of Orissa and Andhra Pradesh produce wider panicles; while head width is less in the compact oval forms of race durra found in Central India.

Head compactness and shape. Head compactness and shape are important characters in determining grain yield and are useful for varietal identification and classification. Head compactness seems to be associated with the humidity of the environment at flowering and ripening time, and very dense panicle are found in those types which flower and ripen grain under extremely dry conditions with compact durra sorghums being outstanding. In contrast loose drooping panicle forms were found in high rainfall areas of the hilly regions of the Eastern Ghats which facilitate drying of the panicle faster, thus preventing grain molds. Almost all the panicle shapes were found in Madhya Pradesh, Andhra Pradesh, and Bihar. The predominant forms are compact elliptic followed by semi-compact elliptic forms (Table 6). Panicles with semi-loose drooping branches, very loose drooping branches which are characteristic features of the wild forms are very rare.

Though threshability is an important evolutionary trait (Harlan, 1992), it is also an important agronomic trait where farmers prefer free threshing cultivars. The majority of accessions are either freely threshable or partly threshable forms, because of strong preference by farmers for such types. There are very few accessions which are difficult to thresh.

\section{Grain characters}

Grain weight. Grain size which is expressed as weight of 100 grains ranged from 0.6 to $7.3 \mathrm{~g}$, the mean grain mass ranged from 2.1 to $3.3 \mathrm{~g}$ (Table 5). Larger grains were found from Madhya Pradesh, Maharashtra, Andhra Pradesh and Karnataka while grain size was less in Orissa and Punjab.

Grain color. The majority of accessions produced straw or white colored grains while accessions with gray, purple and red colored grains were very few. This is due to sorghum in India being grown for food, where consumers prefer white or straw colored grains. Red or reddish brown grains were found in Bihar, Punjab and Uttar Pradesh where sorghum is also grown for forage. Yellow grains were common in Andhra Pradesh, Maharashtra, Rajasthan and Karnataka. Accessions with purple, gray and chalky white were very few.

Subcoat, luster, and endosperm texture. The presence of a subcoat imparts color to the food being prepared (Mushonga \& Appa Rao, 1986), and it is believed by farmers in Zimbabwe to contribute to 
Table 7. Geographic distribution of sorghum races in different states in India

\begin{tabular}{lrrrrrrrrrrrr}
\hline Race & AP & BH & GR & KN & MP & MR & OR & PJ & RJ & TN & UP & Total \\
\hline Bicor & 16 & 4 & 1 & 1 & 5 & 9 & 2 & 26 & 7 & 56 & 21 & 148 \\
Caudatum & 29 & 1 & 4 & 23 & 9 & 22 & 0 & 5 & 4 & 7 & 7 & 111 \\
Durra & 424 & 28 & 179 & 337 & 534 & 586 & 5 & 43 & 180 & 132 & 154 & 2602 \\
Kafir & 4 & 0 & 0 & 0 & 0 & 1 & 0 & 0 & 0 & 0 & 0 & 5 \\
Guinea & 77 & 103 & 3 & 15 & 155 & 15 & 129 & 2 & 0 & 24 & 8 & 531 \\
Durra-caudatum & 59 & 22 & 4 & 33 & 19 & 24 & 3 & 6 & 4 & 10 & 22 & 206 \\
Guinea-caudatum & 60 & 10 & 1 & 18 & 5 & 5 & 3 & 1 & 0 & 6 & 1 & 110 \\
Durra-bicolor & 66 & 7 & 7 & 150 & 27 & 54 & 1 & $5 I$ & 37 & 9 & 17 & 426 \\
Caudatum-bicolor & 5 & 4 & 0 & 7 & 5 & 4 & 1 & 4 & 1 & 3 & 5 & 39 \\
Guinea-bicolor & 2 & 2 & 1 & 3 & 7 & 1 & 3 & 1 & 0 & 1 & 0 & 21 \\
Guinea-durra & 24 & 5 & 0 & 2 & 16 & 1 & 3 & 1 & 0 & 2 & 1 & 55 \\
Guinea-kafir & 1 & 0 & 0 & 0 & 0 & 0 & 0 & 0 & 0 & 0 & 0 & 1 \\
Kafir-bicolor & 5 & 0 & 0 & 0 & 0 & 0 & 0 & 0 & 0 & 1 & 0 & 6 \\
Kafir-caudatum & 1 & 0 & 0 & 0 & 1 & 1 & 0 & 0 & 0 & 0 & 1 & 4 \\
Kafir-dura & 2 & 1 & 0 & 4 & 0 & 5 & 0 & 4 & 0 & 3 & 5 & 24 \\
Total & 775 & 187 & 200 & 593 & 783 & 728 & 150 & 144 & 233 & 254 & 242 & 4289 \\
\hline
\end{tabular}

$\mathrm{AP}=$ Andhra Pradesh, $\mathrm{BH}=\mathrm{Bihar}, \mathrm{GR}=$ Gujarat, $\mathrm{KN}=$ Kamataka, MP = Madhya Pradesh, MR = Maharashtra, $\mathrm{OR}=$ Orissa, $\mathrm{PJ}=$ Punjab, RJ = Rajasthan, $\mathrm{TN}=$ Tamil Nadu, UP = Uttar Pradesh.

insect resistance (Appa Rao \& Mushonga, 1987). In Indian germplasm the subcoat is mainly absent (3281 accessions). In the majority of accessions from Andhra Pradesh, Karnataka, Maharashtra and Rajasthan subcoat is absent. The subcoat is present in very few (323) accessions which are mainly from Punjab where mostly fodder types are grown (Table 7). In India sorghum is primarily grown for food, consequently there has been a strong selection for accessions in which the subcoat is absent. This is in contrast to sorghum in southern Africa where the subcoat is present and where the grain is used for brewing traditional beer (Doggett, 1988). Accessions with lustrous grains, in which the subcoat is absent, predominate (3799) compared to non-lustrous grain in which the subcoat is present. The former commands a premium as it is preferred for food (Desikachar, 1982; Rooney and Miller, 1982). Though there is considerable diversity for endosperm texture, partly corneous types predominate. The sorghum of the subrace roxburghii which are predominantly grown in hilly areas, produce nearly or completely corneous grain.

\section{Classification}

Instead of wading through the 31 categories of Snowden's key for cultivated sorghums (Snowden, 1936), or attempting to choose one of the 63 working groups of
Murty et al., (1967), it is possible to classify sorghum into five basic and ten intermediate races by examining grain shape, glumes and panicles (Harlan \& de Wet, 1972; de Wet, 1978; Harlan, 1992). All the five basic and ten intermediate races were found in India (Table 1). The most commonly found race is durra followed by guinea and durra-bicolor (Table 9). In the important sorghum growing states (Maharashtra, Karnataka and Andhra Pradesh) race durra is extensively grown. Most of the sorghums grown in the postrainy season and which are reputed to possess excellent grain quality belong to the race durra. The race durra is also popular in Yemen where the word durra is used to denote any race of sorghum (App Rao et al., 1993). Members of the race durra have moderate levels of drought resistance and very large panicles as in Yemen (Appa Rao et al., 1993), and in Namibia (Appa Rao et al., 1992). Sorghums of race Durra were probably introduced about a thousand years ago from the Horn of Africa through Yemen, Saudi Arabia and were carried to India either through the Punjab to northern India, or through Sind to Peninsular, India and southern India (Doggett, 1988). The race kafir and its intermediate forms are rare in India. The few accessions belonging to race kafir in Andhra Pradesh may belong to the recent introductions assembled during 1962 to 1967 in Rajendranagar, Hyderabad by the Rockefeller Foundation (Murty et al., 1967) and at ICRISAT since 1972. 
The race Kafir which is indigenous to Southern Africa (Harlan, 1992; Appa Rao et al., 1992) did not reach India along with other races. Subrace roxburghii of race guinea with small corneous endosperm are extensively grown in the tribal inhabited areas of Andhra Pradesh, Bihar, Madhya Pradesh, and Orissa probably because of their grain mold resistance and/or strong preference for such grain where the whole grain is cooked like rice (Prasada Rao et al., 1989).

\section{Resistance traits}

The world collection of sorghum assembled at IAC has been screened under artificially infested epiphytotic conditions by scientists of various disciplines to identify sources of resistance to biotic and abiotic stress factors. (Bandyopadhyay et al., 1988; Nwanze et al., 1991; Sharma, 1993; Sharma et al., 1992; Sharma et al., 1994). Sources of resistance to several biotic stress factors were identified from Indian germplasm (Prasada Rao et al., 1989; Mengesha, 1992). The majority of the resistance sources for shoot fly, stem borer and striga originate from India. Resistance to grain mold, anthracnose, midge, rust and several other factors was also found. Several of these resistance sources have been utilized in ICRISAT (Prasda Rao et al., 1989; Stenhouse, 1993; Reddy \& Stenhouse, 1994), to develop cultivars possessing multiple resistance to one or more stress factors.

Wide environmental adaptation to different seasons, soils and climatic conditions, has lead Indian sorghums exhibiting a wide range of diversity with respect to crop duration, panicle morphololgy, grain morphology, grain quality and racial diversity. Based on morphological and racial diversity of sorghum, India could be considered as the secondary center of diversity.

\section{Possible use of Indian sorghums}

The diversity available in Indian sorghum indicates that a vast panorama of possibilities exist for improving the sorghum plant for grain, fodder and industrial uses. Though there are several landraces with many desirable traits they are not being presently used in sorghum improvements as they are associated with excessive vegetative growth and late maturity. Hence, such landraces need to be converted into early maturity with reduced plant height by repeated backcrossing as was done by Stephen et al., (1967) to facilitate extensive utilization of germplasm. At ICRISAT the zera zera from
Ethiopia were already converted into three height and maturity groups (Prasada Rao et al., 1989) and there is need to convert the Indian sorghum landraces. As the Indian sorghums were found to have stable resistance to several pests and diseases, incorporation of stable resistance into elite genetic background will minimize the use of toxic chemicals leading to environmentally friendly and sustainable sorghum production in the semi-arid tropics.

\section{Acknowledgements}

Several organizations, universities, and institutes in India had liberally donated sorghum germplasm to ICRISAT. We are particularly grateful to the All India Coordinated Sorghum Improvement Project, Rajendranagar and the national bureau of plant genetic resources, who had participated in joint germplasm collection missions to different states in India. Thanks are due to Dr.J.W. Stenhouse, Principal Scientist, Dr.B.V. Subba Reddy, Senior Scientist, ICRISAT, Mr C. Janardhan Reddy, Technical Assistant, and Mr D. Bapa Rao, Field Helper, GRD, ICRISAT for their help.

\section{References}

Anahosur, K.H., 1992. Sorghum diseases in India. pp. 45-56. In: W.A. de Miliano, J. Frederiksen, R.A. \& Bengston, G.D. (Eds) Sorghum and millets diseases: a second world review. Patancheru. ICRISAT.

Appa Rao, S, L.R. House \& S.C. Gupta, 1989. A review of sorghum, pearl millet and finger millet imrovement in SADCC countries. Gaborone, Botswana: SACCAR and Bulawayo, Zimbabwe: SADCC/ICRISAT. pp 170.

Appa Rao, S., E.S. Monyo, L.R. House, M.H. Mengesha \& I Negumbo, 1992. Germplasm collection mission to Namibia FAO/IBPGR Plant Genetic Resources Newsletter. 90: 42-45

Appa Rao, S., A.W. Mukred, M.H. Mengesha, Hassan M. Amer, K.N. Reddy, Ali Alsurai \& M.A. Saeed, 1993. Collecting crops germplasm in Yemen. FAO/IBPGR Plant Genet. Resou Newsletter 94/95:28-31.

Appa Rao, S. \& J.N. Mushonga, 1987. A catalogue of passport and characterization data of sorghum, pearl millet and finger millet from Zimbabwe. Rome, Italy: IBPGR. pp 74.

Bandyopadhyay, R., L.K. Mughogho \& K.E. Prasada Rao, 1988. Sources of resistance to sorghum grain molds. Plant Dis 72: 504 508.

Bantilan, M.C.S. \& P.K. Joshi, 1994. Evaluating ICRISAT research impact; summary proceedings of a workshop on research. evaluation and impact assessment. 13-15 Dec. 1993, IAC, ICRISAT, pp 148.

Brown, A.H.D., 1989. The case for core collection. pp. 136-156. In: A.H.D. Brown, O.H. Frankel, D.R. Marshall \& J.T. Williams (Eds). The use of plant genelic resources. Cambridge University Press, Cambridge. 
Byth, D.E. (Ed), 1993. Sorghum and millets commodity and research environments. Patancheru, ICRISAT.

Dahlberg, J., 1993. The U.S. sorghum germplasm collection. pp 2128. In: Grain sorghum-The crop of the future. National grain sorghurn producers, Abermathy, Texas, USA

Desikachar, H.S.R., 1982. Pearling and milling studies on sorghum, pp. 194-199, In: Proc Intern Symp sorghum grain quality, 28-31 Oct. 1981. ICRISAT.

Deu, M., D. Gonzalez-de-Leon, J.C. Glaszmann, I. Degremont, J. Chanterenu, C. Lanaud \& P. Hamon, 1994. RFLP diversity in cultivated sorghum in relation to racial differentiation. Theor Appl Genet 88: 838-844.

de Wet, J.M.J., 1978. Systematics and evolution of sorghum sect. Sorghum (Gramineae). Amer. J. Bot. 65: 477-484.

Doggett, H., 1988. Sorghum (second edition). London, UK. Longman. pp. 512 .

Duncan, R.R., P.J. Bramel-Cox \& F.R. Miller, 199l. Contributions of introduced sorghum germplasm to hybrid development in the USA. In: H.L. Shands \& L.E. Wiesner (Eds). Use of Plant Introduction in Cultivar Development Part I, Crop Sci Soc of Amer spl publ Madison, WI. Number 17: 69-102.

Duncan, R.R., J.A. Dahlberg \& M.S. Spinks. 1993. International activities in sorghum germplasm during the past twenty years. ASA Special Pub.

Eberhart, S.A., 1993. Concept of worldwide germplasm utilization. pp 12-16. In Grain sorghum-Crop of the future. National grain sorghum producers, Abernathy, Texas, USA.

FAO (Food and Agrictulture Organization), 1993. FAO production year book 1992. 46:92.

Harlan, J.R., 1992. Crops and Man. Madison, Wisconsin, CSSA, Inc pp 272.

Harlan, J.R. \& J.M.J. de Wet, 1972. A simple classification of cultivated sorghum. Crop Sci 12: 172-176.

House, L.R., 1985. A guide to sorghum breeding. Patancheru, A.P., India: ICRISAT. pp 206.

Lodhi, G.P., 1993. Potential for forage sorghum in Asia. pp. 12-15. In: Collaborative sorghum research in Asia, Patancheru, India, ICRISAT.

Mathur, P.N., K.E. Prasada Rao, I.P. Singh, R.C. Agrawal, M.H. Mengesha \& R.S. Rana, 1992. Evaluation of forage sorghum germplasm part-2. New Delhi, NBPGR. pp 296.

Mann, J.A., C.T. Kimber \& F.R. Miller, 1983. The origin and early cultivation of sorghum in Africa. Texas A\&M. Univ., Texas Agric Exp Stn Bull 1454.

Mengesha, M.H., 1992. Genetic stocks in world collection: Useful genetic stocks in the world collection of gemplasm maintained at ICRISAT pp 140-162. In: M.S. Swaminathan \& S. Jana (Eds) Biodiversity implications for global food security. Madras, Macmillan India Limited.

Mengesha, M.H. \& S. Appa Rao, 1994. Management of plant genetic resources at ICRISAT, pp 11-14. In: Evaluating ICRISAT Research Impact, IAC, Patancheru, ICRISAT.

Murty, B.R., V. Arunachalam \& M.B.L. Saxena, 1967. Classification and catalogue of a world collection of sorghum. Indian $\mathrm{J}$ of Genet and Pl Breed 27:1-194.
Murty, U.R., 1992. Technology for increasing sorghum production in India. National Research Centre for Sorghum, Hyderabad, India. pp. 67.

Mushonga, J.N. \& S. Appa Rao, 1986a. Traditional food crops of Zimbabwe. II. Sorghum. Zimbabwe Agrl J. 83: 121-124.

Mushonga, J.N. \& S. Appa Rao, 1986b. Dehulling of sorghum grain. pp. 248-257. Pro Sec Reg Workshop on Sorghum and millet, Bulaway, OSADCC/ICRISAT.

Nwanze, K.F., Y.V.R. Reddy, S.L. Taneja, H.C. Sharma \& B.L. Agarwal, 1991. Evaluating sorghum genotypes for multiple resistance. Insect Science and its applications 12: 183-188.

Paroda, R.S. \& R.K. Arora, 1992. Genetic resources, crop improvement and sustainable agriculture. pp 59-79. In: M.S. Swaminathan \& S. Jana, (Eds). Biodiversity-Implications for global food security. Macmillan India, Madras.

Prasada Rao, K.E., M.H. Mengesha \& V. Gopal Reddy. 1989. International use of sorghum germplasm collection. 49-67. In: A.H.D Brown, D.R. Marshall, D.H. Frankel \& J.T. Williams (Eds). The use of plant genetic resources. Cambridge University Press, Cambridge, U.K.

Prasada Rao, K.E. \& V. Ramanatha Rao, 1995. The use of characterization data in developing a core collection. pp 109-115. In: T. Hodgkin, A.H.D. Brown, Th.J.L. Hintum \& E.A.V. Morales, (Eds) Core collections of plant genetic resources. John Wiley \& Sons, Chichester.

Rao, N.G.P., 1982. Transforming traditional sorghums in India. pp 39-60 In: N.G.P. Rao \& L.R. House (Ed) Sorghum in the Eighties: Proceedings Intern. Symp. on Sorghum, 2-7 Nov, 1981, Patancheru, ICRISAT.

Reddy, B.V.S. \& J.W. Stenhouse, 1994. Genetic enhancement research on sorghum at JCRISAT. pp 15-18. In: Evaluating ICRISAT Research Impact, IAC, Patancheru, ICRISAT.

Rooney, L.W. \& F.W. Miller, 1982. Variation in the structure and kernel characteristics of sorghum. pp 143-162; In: Proceedings Intem. Symp. sorghum grain quality, 28-31 Oct. 1981, IAC, Patancheru, ICRISAT.

SAS Institute, 1982. SAS user's guide: Statistics. Cary, NC USA, SAS Institute

Sharma, H.C., 1993. Host-plant resistance to insects in sorghum and its role in integrated pest management. Crop Protection 12: 11-34.

Sharma, H.C., B.V.S. Reddy, J.W. Stenhouse \& K. Nwanze, 1994. Host plant resistance of sorghum midge, Contarina sorghicola. International sorghum and millets newsletter 35: 30-40.

Sharma, H.C., S.L. Taneja, K. Leuchner \& K.F. Nwanze, 1992. Techniques to screen sorghum for resistance to insect pests. Patancheru, ICRISAT.

Stephens, J.C., F.R. Miller \& D.T. Rosenow, 1967. Conversion of alien sorghums to early combine genotypes. Crop Sci 7: 396.

Stenhouse, J.W., 1993. Overview of ICRISAT's research on sorghum. pp. 25-28. In: Collaborative sorghum research in Asia, Patancheru, ICRISAT.

Snowden, J.D., 1936. The cultivated races of sorghum. London, UK, Adlard.

Swaminathan, M.S. \& S. Jana (Eds), 1992. Biodiversity implications for global food security. Macmillan India, Madras. pp. 326. 